\title{
Inherited Epidermolysis Bullosa - A Case Report of Several Family Members in Three Generations
}

\author{
Ljuba VUJANOVIĆ ${ }^{1,2}$, Marina JOVANOVIĆ ${ }^{1,2}$, Zoran GOLUŠIN ${ }^{1,2}$, \\ Svetlana KOVAČIĆ DUKIĆ ${ }^{1}$, Sanja JAKOVLJEVIĆ ${ }^{1}$, Miloš NIŠAVIĆ 1,2 \\ ${ }^{1}$ Clinic of Dermatovenereology Diseases, Clinical Center of Vojvodina, Novi Sad, Serbia \\ ${ }^{2}$ Department of Dermatovenereology, Faculty of Medicine, University of Novi Sad, Serbia \\ *Correspondence: Ljuba Vujanović, E-mail: ljuba.vujanovic@mf.uns.ac.rs
}

UDC 616.591-002.1-056.7

\begin{abstract}
Inherited epidermolysis bullosa (IEB) is a genodermatosis transmitted in either autosomal dominant or autosomal recessive manner. The disease is characterized by the development of blisters, erosions, scars, nail dystrophy and scalp abnormalities. Our case report has included four members of one family in three generations with manifested disease. Our 25-year-old female patient presented with a few eroded, crusted, nummular lesions localized on the dorsal plate of interphalangeal joints of fingers, elbow and knee skin, while anonychia was found on her digits. Our youngest patient (her 3.5-year-old son) presented with the lesions in the form of blisters filled with serous fluid, erosions, recent scars and atrophy. Some atrophic scars on the elbow and knee skin were found in our patient's younger brother, aged 16 . The 46-year-old mother of our female patient had nail dystrophy on her hands accompanied by the toenails absence. Pediatric geneticist created the pedigree chart which showed autosomal dominant inheritance pattern with complete expressivity and penetrance. Further diagnostics was not done because the family was not interested.
\end{abstract}

Key words: Epidermolysis Bullosa Simplex; Skin Diseases, Genetic; Skin Diseases, Vesicobullous; Signs and Symptoms; Case Reports

\section{Introduction}

Inherited epidermolysis bullosa (IEB) belongs to a group of genodermatoses transmitted in either autosomal dominant or autosomal recessive manner, characterized by blistering spontaneously or following minor trauma (1). It encompasses four major forms: simplex, junctional, dystrophic, Kindler syndrome and over 30 different clinical phenotypes (1-3). IEB can result from mutations within genes that encode structural proteins sited in epidermis, dermo-epidermal junction or uppermost papillary dermis, resulting in cleavage and blister formation (2). The disease is characterized by the development of blisters, erosions, scars, scalp abnormalities and nail dystrophy. The clinical manifestations of IEB vary in accordance with the type of disease, and diagnosis could be determined only by skin biopsy and immunofluorescence or electron microscopy (1).

\section{Case Report}

A 25-year-old female was referred for dermatologic examination with a suspicion of a drug allergy. On admission, a few eroded, crusted, nummular lesions localized on the dorsal plate of interphalangeal joints of fingers, elbow and knee skin were present. Besides, anonychia on the feet was also found (Figure 1). Her personal history revealed that the skin changes first appeared two days after birth. The skin lesions were localized on the right hand fingers, shins and around external malleolus of the ankles. The patient noted some improvement after the age of 10 when the blisters occurred more rarely; however, the condition deteriorated during summer. The oral cavity was not affected throughout the disease. The family history revealed that the same lesions were present in our patient's mother, younger brother and one son from her twin pregnancy. Out of the thirty members of the patient's great-grandmother's family, 13 suf- 

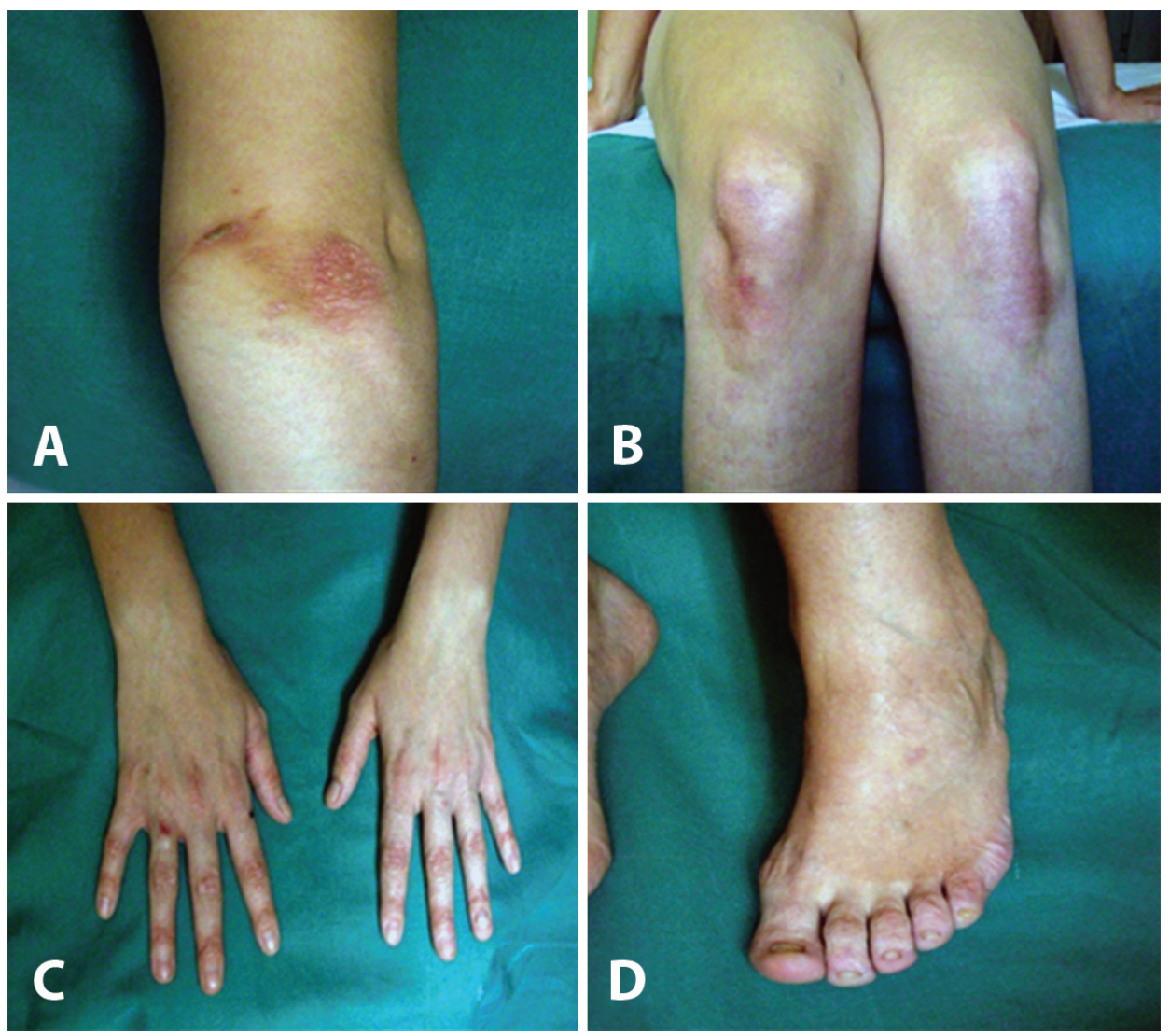

Figure 1. Our female patient: A) eroded and crusted lesions on the elbows; B) eroded and crusted lesions on the knees; C) eroded, crusted, nummular lesions localized on the dorsal plate of interphalangeal joints of fingers; D) anonychia on the feet

fered from EBS, while the rest of relatives had had atopic dermatitis. The relatives of our patient with similar skin condition were thoroughly examined. Her 3.5-year-old twin son presented with erythematous recent scars, having atrophic appearance. Similar lesions with scarring and ulcerations and blisters filled with serous fluid sized $2 \mathrm{~cm}$ in diameter were found on the right elbow. In addition, fresh erosions, crusts and milia on the feet and epithelized erosion on lateral malleolus were visible (Figure 2). Our patient's younger brother, aged 16, was found to have atrophic scars with slight central hypertrophy on the elbow and knee skin (Figure 3) with apparent anonychia. The mother of our patient, aged 46, presented with nail dystrophy on her hands accompanied by the toenails absence (Figure 4).

A pediatric geneticist constructed the pedigree chart in order to interpret autosomal dominant inheritance pattern with complete expressivity and penetrance (Diagram 1). The patient as well as the members of her family refused further diagnostics.

\section{Discussion}

Inherited epidermolysis bullosa was first described in 1870 by von Hebra, whereas the current title epidermolysis bullosa hereditaria was given by Koebner in 1886. Twelve years later, in 1898, Hallopeau identified a distinction between the clinical presentation of simplex and dystrophic forms. Furthermore, in 1962, Pearson established the precise characterization of three major forms (simplex, junctional, dystrophic) by means of transmission electron microscopy. In the following decades, due to the development in science, technology and technical achievements, additional IEB phenotypes were described. Moreover, monoclonal antibody studies suggest the existence 

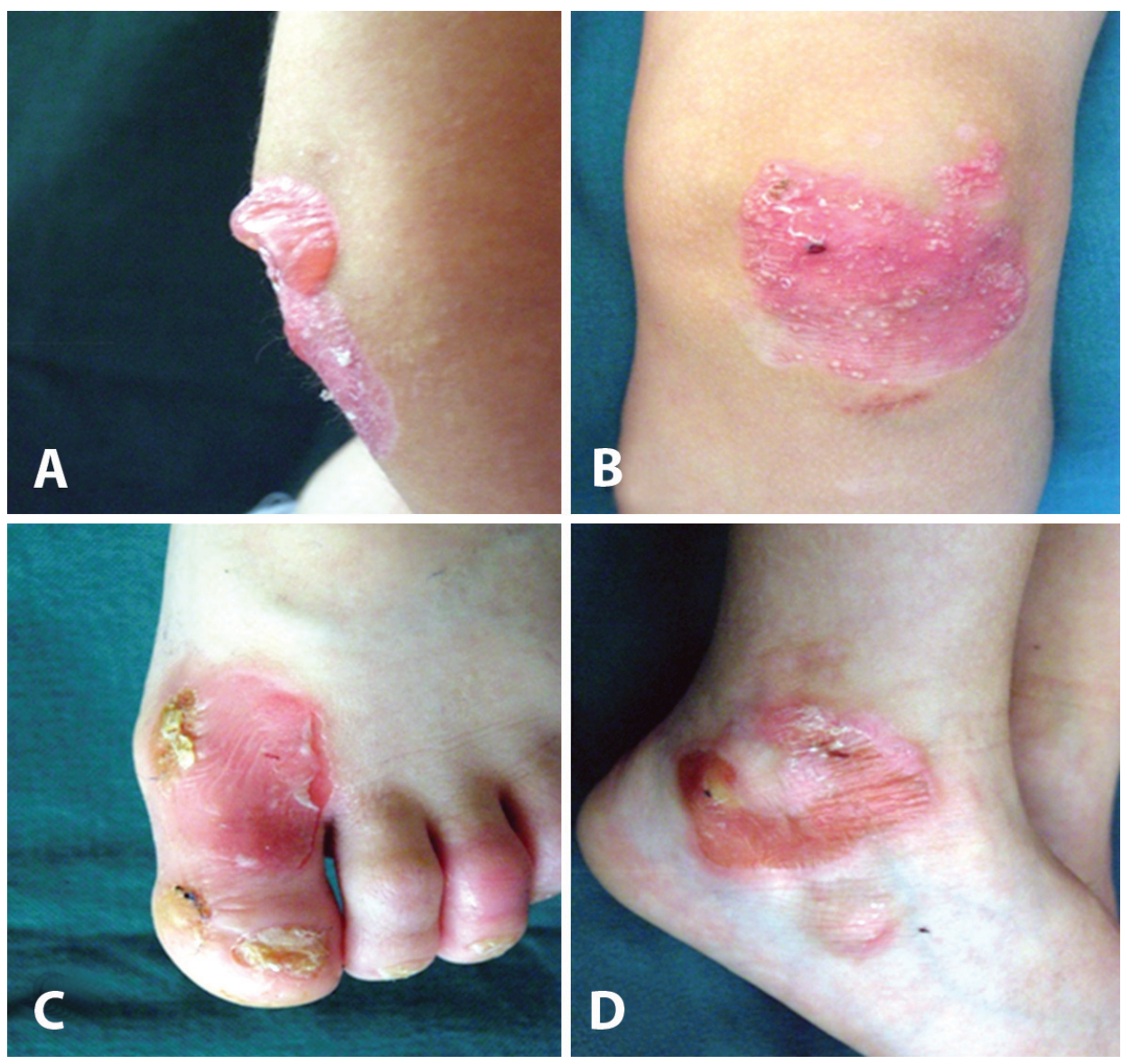

Figure 2. Her son: $A)$ recent scars and ulcerations and blister filled with serous fluid sized $2 \mathrm{~cm}$ in diameter resided on the right elbow; B) recent atrophic scar on the knee and marginal milia; C) fresh erosions, crusts and milia on the feet; D) epithelialized erosion on the lateral malleolus

of specific protein defects in each type and subtype (2). Depending on the ultrastructural level of cleavage, the antigenic alteration in the skin, inheritance pattern and clinical features, IEB is divided in epidermolysis bullosa simplex (EBS), junctional epidermolysis bullosa (JEB), dystrophic epidermolysis bullosa (DEB) and Kindler syndrome $(2,3)$.

EBS is transmitted in the autosomal dominant manner as it happened in our patient and her relatives. Besides, EBS could be inherited in the autosomal recessive manner resulting in a severe clinical form associated with muscular dystrophy and pyloric atresia. In addition to the generalized form known as Koebner subtype, there have been reports on the localized form named Weber-Cockayne subtype that presents most often with a milder form of IEB as well as EBS herpetiformis named Dowling-Meara subtype. In all subtypes, intraepidermal blisters are developed soon after birth. Because of the early appearance of blisters and generalized distribution of skin lesions in our patient as well as in other patients included in this case report, our opinion was that all of them might have suffered from Koebner subtype. However, milia were visible on the lower extremities in our youngest patient, the 3.5-year-old son of our female patient. For that reason and since no biopsy for histopathological examination had been performed, we considered other forms of IEB with clinical picture of milia. At first, we thought it was DEB that can be transmitted in either autosomal dominant or autosomal recessive manner (3), characterized by an early appearance of blisters with tendency of localization during maturation. Dominant dys- 


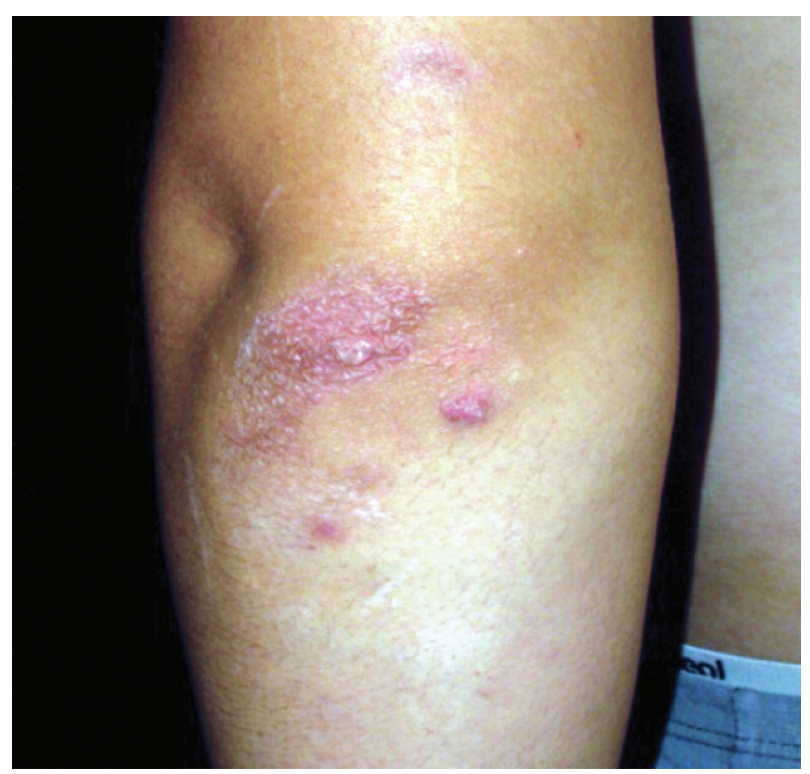

Figure 3. Her brother: atrophic scars with slight central hypertrophy on the elbow

trophic epidermolysis bullosa (DDEB) includes two subtypes, more often form, Cockayne-Touraine, with acral distribution of lesions and rarely affected oral cavity, and Pasini variant manifesting excessive oral lesions and severe blistering. Nail dystrophy or anonychia is common in both entities, with distinctive scarring: Cockayne subtype is characterized with hypertrophic scars, Pasini variant results in atrophic scars. Multiple milia as an isolated skin manifestation without a previous blister formation could be a primary manifestation of DDEB (4). Due to the fact that neither of our patients presented with oral lesions, and according to the literature data revealing the rare occurrence of atrophy and milia in Koebner subtype of EBS (5), we suggested the possible existence of this form of EBS. In this subtype, the wound almost always heals with no scarring, while the aggravation may develop in summer as it happened to our patient. Nail dystrophy may occur in severe forms of disease. Following the examination of all patients it may be concluded that clinical expressivity of lesions declines with years. The literature describes frequency of Koebner form with prevalence of about 2 per a million (6).

The diagnosis can be determined on the basis of anamnesis, clinical characteristics, histopathological analysis of the biopsy specimens (a recent blister) and by antigenic mapping and identifying specific agents responsible for pathogenic mutations (7). In addition to this, in their study, Tampoia et al. have suggested that the IL-6/IL-10 ratio can be used as a prognostic and predictive marker of the severity of IEB and it has been reported that this ratio is statistically higher in recessive DEB than in EBS and healthy subjects (8). Apart from immunofluorescence antigen mapping, immunohistochemistry staining could be used as a diagnostic method especially in resource-limited settings (9). Histopatho-

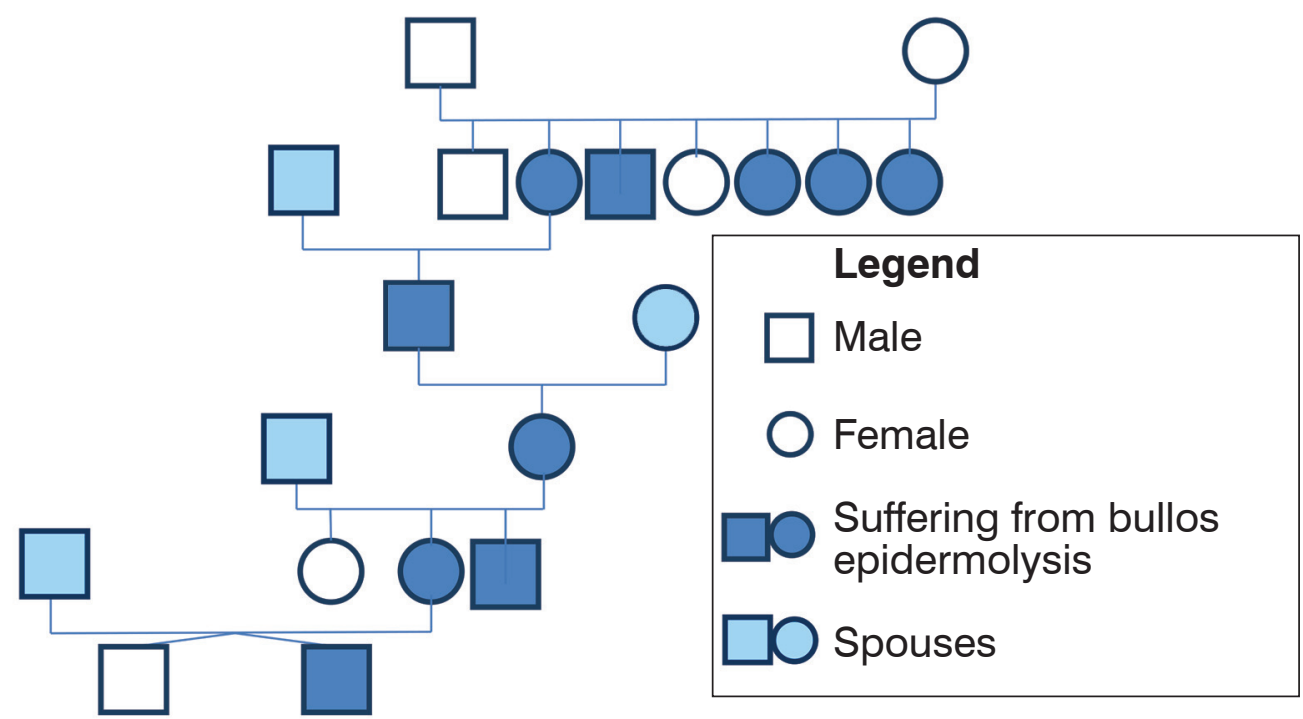

Diagram 1. Pedigree chart 


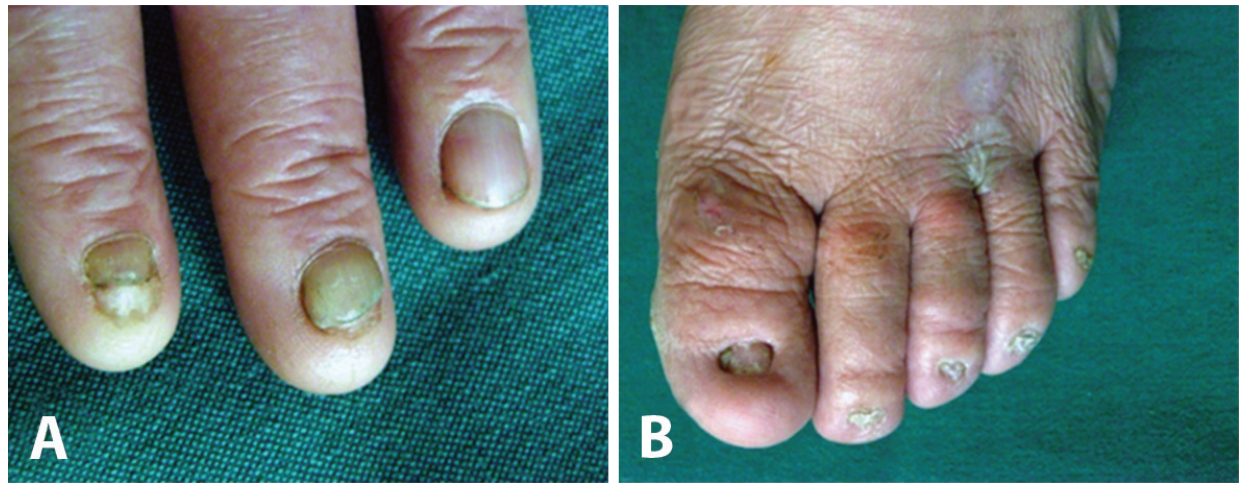

Figure 4. Mother: A) nail dystrophy on the hands; (B) anonychia on the feet

logical examination was not performed because the patient did not consent to it, therefore we do not have evidence of cleavage level, although it is known that EBS is characterized by intraepidermal blistering.

There is no specific therapy for any form of IEB. Treatment of IEB is focused on preventing mechanical trauma and infections (2). Treatment of newborns is managed by neonatologists and dermatologists in intensive care units. The aims of therapy are prevention of appearance of new lesions by intensive care, gentle manipulations, soft padding and adequate, easily removed clothes. A number of dressings are available for wounds. As a general rule, those that are non-adhesive and easily changed should be applied to the lesions (2). Topical and systemic antibiotics should be administered for short periods according to the recommendations in order to avoid bacterial resistance and sensitization (1). Patients suffering from severe forms require attentive monitoring and additional interventions such as different medical, surgical, dental, nutritive and psychological consultations (1). All potential parents with positive family history should be referred to genetic counselor so as to establish the diagnosis, type and subtype of IEB. EBS does not generally require invasive prenatal diagnosis. However, chorionic villus sampling is essential in recessive forms (3).

\section{Conclusion}

In spite of a small number of patients affected by inherited epidermolysis bullosa and low demand for examination of patients suffering from mild forms of the disease, the im- plementation of available diagnostic procedures is required. Monitoring, genetic counseling and support in emotional suffering, physical pain and economic burden must be provided to patients and their families.

\section{Abbreviations}

IEB - inherited epidermolysis bullosa EBS - epidermolysis bullosa simplex JEB - junctional epidermolysis bullosa DEB - dystrophic epidermolysis bullosa IL6 - interleukin 6

IL10 - interleukin 10

\section{References}

1. Boeira VL, Souza ES, Rocha Bde O, Oliveira PD, Oliveira Mde F, Rêgo VR, et al. Inherited epidrmolysis bullosa: clinical and therapeutic aspects. An Bras Dermatol. 2013;88(2):185-98.

2. Bolognia JL, Jorizzo JJ, Schaffer JV, Callen JP, Cerroni L, Heymann WR, et al. Dermatology. 3rd ed. London: Elsevier; 2012.

3. Karadaglić Đ. Dermatologija. 2nd ed. Beograd: Karadaglić Đ; 2016.

4. Akasaka E, Nakano H, Takagi Y, Toyomaki Y, Sawamura D. Multiple milia as an isolated skin manifestation of dominant dystrophic epidermolysis bullosa: evidence of phenotypic variability. Pediatr Dermatol. 2017;34(2):e106-8.

5. Wolff K, Goldsmith L, Katz S, Gilchrest B, Paller AS, Leffell D. Fitzpatrick's dermatology in general medicine. 7th ed. New York: McGraw-Hill; 2008.

6. Khare S, Agarwal D, Pathak S, Kumar R. EpidermoIysis bullosa simplex- Koebner: a case report. Indian Journal of Neonatal Medicine and Research. 2016;4(1):7-9.

7. Sánchez-Jimeno C, Escámez MJ, Ayuso C, TrujilloTiebas MJ, Del Río M. Genetic diagnosis of epider- 
molysis bullosa: recommendations from an expert Spanish research group. Actas Dermosifiliogr. 2018;109(2):104-22.

8. Tampoia M, Abbracciavento L, Morrone M, Fumarulo $\mathrm{R}$. IL-6/IL-10 ratio as a prognostic and predictive marker of the severity of inherited epidermolysis bullosa. Iran J Immunol. 2017;14(4):340-9.
9. Yenamandra VK, Bhari N, Ray SB, Sreenivas V, Dinda AK, Scaria V, et al. Diagnosis of inherited epidermolysis bullosa in resource-limited settings: immunohistochemistry revisited. Dermatology. 2017;233(4):326-32.

\section{Nasledna bulozna epidermoliza - prikaz nekoliko članova porodice iz tri generacije}

\section{Sažetak}

Epidermolysis bullosa hereditaria je genodermatoza koja se nasleđuje autozomno dominantnim ili autozomno recesivnim putem. Bolest se manifestuje stvaranjem bula, erozija, ožiljaka, distrofijom nokatnih ploča i abnormalnostima skalpa. Prikazujemo četiri člana jedne porodice u tri generacije kod kojih se bolest manifestovala. Kod naše bolesnice (25 godina) postojale su erodovane, krustozne, numularne promene na dorzumima interfalangealnih zglobova prstiju šaka, na koži laktova i kolena, dok je na prstima postojala anonihija. Kod najmlađeg bolesnika (sin naše bolesnice, 3,5 go- dina) uočavale su se promene na mestima pritiska u vidu bula ispunjenih bistrim sadržajem, erozija, svežih ožiljaka i atrofije. Kod brata naše bolesnice (16 godina) bili su prisutni atrofični ožiljci na laktovima i kolenima. Majka naše bolesnice (46 godina) imala je distrofične nokatne ploče na šakama uz anonihiju na stopalima. Genetičar je izradio porodično stablo iz kog se vidi da se bolest nasleđuje autozomno dominantno uz potpunu ekspresivnost i penetrantnost gena. Dalja dijagnostika nije rađena, jer porodica nije bila zainteresovana.

Ključne reči: Bulozna epidermoliza simpleks; Genetske kožne bolesti; Vezikobulozne kožne bolesti; Znaci i simptomi; Prikazi slučajeva 